\title{
Environmental management of a highly impacted, urbanized tropical estuary: rehabilitation and restoration
}

\author{
A. Thorhaug \\ Department of Biological Sciences, Florida International University; \\ Miami, Florida, USA
}

\begin{abstract}
The principles of the dynamics and interrelationships within the dominant subtropical and tropical Caribbean seagrass community have been studied previously before, during, and after impact. From these and scores of observations of damage and recovery patterns in Thalassia ecosystems, a sense of management recovery strategy has emerged. Artificial restoring of Thalassia testudinum seeds into areas cut off from stock (fruit, seeds) appeared feasible on a large scale after the Turkey Point (Biscayne Bay, Miami, Florida) restoration and test sampling throughout North Biscayne Bay. Two large-scale seeding attempts were made; after 11 months they compared favorably with Turkey Point specimens with regard to growth parameters, despite the turbidity and other persistent pollution. Thus, the possible areas in which Thalassia seed restoration can be used has increased to include estuaries of multiple impact still in various stages of recovery after physical and sewage pollution. This technique should be especially useful to "developing" nations where important nearshore fisheries nurseries based on Thalassia ecosystems have been heavily damaged and now lie barren. Man's impact on the estuary where seed restoration was attempted includes the following activities: $50 \%$ of the bay bottom directly dredged or filled (leaving much unconsolidated sediment); 50 million gallons of domestic waste dumped directly into a low flushing part of the bay for 20 years; seven major causeways transecting the bay, restricting circulation and flushing; two artificial inlets made into navigational channels; freshwater sheet flow drastically changed due to channelization by flood-control canals; urban runoff from a million people entering the bay. Most of the impacts have now abated; however, their long-term effects remain.
\end{abstract}

\section{INTRODUCTION}

Restoration of marine and estuarine communities as a management tool has lagged far behind restoration of terrestrial communities despite the need for rehabilitation of large areas of impacted estuarine and marine biota which have been badly degraded. Only recently have feasible large-scale techniques been devised to restore damaged marine ecosystems (Thorhaug, 1974; Thorhaug \& Austin, 1976). However, these techniques are not known to all nations or even to many local and United States government agencies, nor are there adequate laws and enforcement procedures to implement them in many nations and states. Particularly in tropical "developing" nations, valuable nearshore fisheries have previously been badly impacted. In addition, large future impacts are planned. The following description should provide a model for these nations. 
Due to the 1969 U.S. National Environmental Protection Act, mitigation is now required for many large projects of impact located in the coastal zone. A person applying for a permit to dredge, fill or emit effluents in the coastal zone often receives the permit only under the condition that he mitigate the damage by planting an equivalent amount of vegetation, either at the same site after the damage is done (if feasible) or at a nearby site already impacted from past damage.

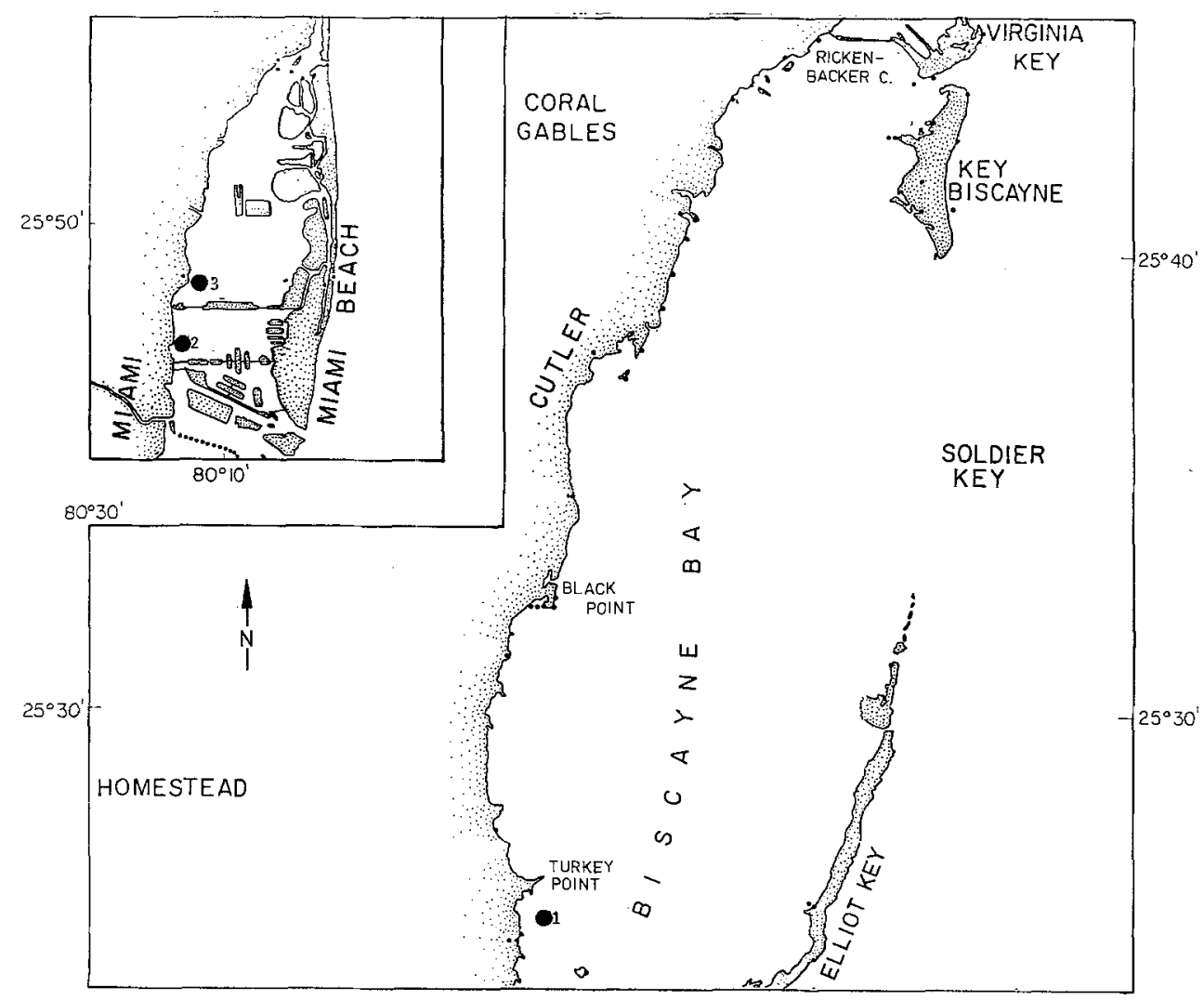

Fig. 1. Location of the impacted sites studied in Biscayne Bay (Florida). $1=$ Turkey Point, $2=36$ th Street Causeway, 3 = Margaret Pace Park

Biscayne Bay (Fig. 1), at the lower edge of the southeast coast of Florida between the cities of Miami and Miami Beach, is one of the large urbanized estuaries remaining on the east coast of the United States not to be irreparably harmed by man's activity. The southern part of the Bay has been made into a national monument by the U.S. Department of the Interior in an attempt to preserve it in a fairly pristine state. The far southern end (including Card Sound) had one major impact - thermal effluents - which was studied by a large group of scientists. The pollution and base-line ecological framework before, during, and after effluents was documented (summarized in Bader \& Roessler, 1971, 1972; Bader et al., 1973; Thorhaug, 1974, in press; Roessler et al., 1974; Thorhaug \& Roessler, 1977; Thorhaug et al., 1979). 
Since 1896, North Biscayne Bay, which is defined as the area north of the Rickenbacker Causeway, has borne a series of impacts due to the rapid and spectacular "real estate boom". Many of these impacts were undocumented so that the original state must be reconstructed from a small information base. The impacts included: (1) dredging and filling more than $50 \%$ of the Bay bottom north of the Rickenbacker Causeway; (2) dumping 50 million gallons of sewage per day for 20 years (McNulty, 1970); (3) making a series of 7 major causeways with no thought to flow (transecting the flow and changing the circulation) (the causeways in good part being constructed from bay bottom material, directly killing benthic communities and smothering more); (4) urban runoff from the Miami River, which included extensive ship construction (heavy metals) runoff, fisheries industry effluents, and sewage with hospital effluents; (5) construction of numerous deep channels for an Intracoastal Waterway and Port down to $35 \mathrm{ft}$. within the area of the Bay which had a natural mean depth of about $6 \mathrm{ft}$. and probably did not reach more than 10-12 ft. maximum depth under natural conditions; (6) change in water runoff by the Flood Control District, which channelized water from sheet flow to the Bay over a large portion of southeast Florida into a few flood-control canals and rivers, changing freshwater drainage to point source, rather than sheet, runoff; (7) opening two artificial and deep channels between the Bay and the ocean, for navigational purposes, which changed circulation, salinity, and other parameters.

To counteract these multiple impacts, in the spirit of the new coastal zone legislation, a concern arose over possible future events. The first strategy was to gather information from those who had worked on the Bay for a variety of reasons and set priorities. Several symposia were called. The first summarized all the available scientific knowledge on the physical, chemical, biological, sociological, legal and urban aspects of Biscayne Bay (Thorhaug, 1976). This was attended by leaders of government, industry, and science. The next weekend, with the symposium proceedings in hand, an American assembly-type meeting for six groups each of twenty people (representing all interested sectors) was convened to go over prearranged important Bay problems. They issued a policy statement on the Bay where four areas were highlighted as needing restoration: (1) biotic restoration of the bottom vegetation, specifically seagrass and artificial reefs; (2) turbidity problems; (3) circulation problems; and (4) shoreline modification.

Working groups were formed during the next months, resulting in a specific symposium on "Restoration of North Biscayne Bay" one and one-half years later, where the above four rehabilitation subjects were discussed in considerable detail particularly by scientists and managers, and where a plan for investigating the feasibility of rehabilitation of North Biscayne Bay was devised. A definite aim was made to seek multiple funding: state and county governments, industry, and real estate developers have shown interest in participating, especially since the Bay has been designated an "aquatic preserve" by the State of Florida so that no impact can occur without state permit.

Due to this "aquatic preserve" designation, when two county agencies found it of "public necessity" to dredge approximately five acres of marine bottom apiece to construct a sewer main (in an area previously dredged for the same) and to increase a ship channel's width adjacent to the Port of Miami, mitigation was written as part of their permit, after a hearing process.

The results described here are the first specific and large-scale attempts to restore the biota of North Biscayne Bay. They are based on the concept of introducing the 
dominant plant species as the biotic food source and as a matrix of habitat for the animals.

A summary of restoration methods for the seagrasses (including the dominant seagrass throughout the south Florida Gulf of Mexico and Caribbean region, Thalassia testudinum) can be found in Thorhaug \& Austin (1976). In brief, early attempts by plug were unsuccessful due to the absence of apical meristem material throughout the rhizomal structure of Thalassia (Tomlinson, 1974). The seeding attempts (Thorhaug, 1974) have been much more successful; thus, the efforts made in North Biscayne Bay to restore the dominant seagrass were all done by seeding.

The basic strategy of these restoration efforts was to directly plant the dominant vegetative species, Thalassia testudinum, a marine angiosperm, which appears to have long recovery time after impact and in Biscayne Bay is at the edge of its North Atlantic range. Elimination of the species by pollution plus barriers to its return (causeways and trenches) have resulted in extremely small patches of Thalassia at very infrequent intervals in North Biscayne Bay.

The first large-scale Thalassia transplantation was carried out in South Biscayne Bay in 1973 by planting two corridors in an area previously denuded by thermal effluents (thence directed offstream) (Thorhaug, 1974). Four years later, densities of seagrasses having 2030 blades $\mathrm{m}^{-2}$ developed, compared with the 2295 in the adjacent control areas which had never been been affected by the heat (Thorhaug, 1979). The seagrasses had flowered and fruited and apparently were reseeding the adjacent areas. (A control for natural reseeding is described below at Cutler Ridge.)

A seasonal study on the animal populations that have recolonized the restored seagrasses in South Biscayne Bay at Turkey Point after four years (McLaughlin \& Thorhaug, 1978, 1979; and McLaughlin et al., in press) showed that there was no statistical difference between the abundance of species and similar diversity indices found in the restored Thalassia and in adjacent control areas which had not been impacted by thermal effluents. A large difference was seen between restored areas and barren areas which had not been restored. Food-web organisms seen in particular numbers were juvenile stages of fishes (total for all months: 351 in restored Thalassia versus 19 in barren unrestored) and juvenile stages of shrimp (163 in restored Thalassia versus 9 in barren unrestored).

Based on this success, an investigation of a series of test locations was undertaken to look at the possibility of restoring Thalassia in the multiple impacted North Biscayne Bay (Thorhaug \& Hixon, 1975). The results from this site showed that growth of seagrass seedlings was possible in North Biscayne Bay; that is, the water quality, after the abatement of most of the pollutants, had returned to a quality capable of sustaining seagrass growth. However, some of the physical conditions, such as the wave action with associated pressures and turbidity from the boat channel and the strong tidal currents induced by channelization, appeared to cause a high mortality rate. The optimal area for planting appeared to be the most central basin which was least flushed and coincidentally had been least impacted during the bottom dredging. 


\section{METHODS}

The 36th Street Causeway, dredged in 1958 from the Bay bottom, is composed of sand. The north side has a very gentle slope. After 20 years, the prevalent vegetation was the seagrasses Halodule wrightii in the shallow water and Syringodium filiforme in the deeper water, with an outer fringe from $8 \mathrm{ft}$. of Halophila baillonis. The previously dominant species (Thalassia) was absent. The basin is the least flushed, but the least impacted in North Bay. Turbidity levels (from aerial and diving observations) are the lowest in this basin for North Biscayne Bay.

The Margaret Pace Park area is located on the middle western bank of the city of Miami, just north of the Venetian Causeway. This park was recently filled with materials brought from upland and the intertidal area filled with riprap; the sublittoral area is sandy but has fine silt and fine muds as one progresses outward. Immediately adjacent to the park within $400-500 \mathrm{~m}$ is the Intracoastal Waterway, a trench of $10 \mathrm{~m}$ dredged by the U.S. Army Corps of Engineers and maintained at regular intervals. The slope is quite steep in some portions at the northern end and fairly gentle at the southern end. Prior to the restoration, there were patches of Halodule wrightii in small areas in the shallower portion of the sublittoral regime, then below $7 \mathrm{ft}$. (high tide) Halophila baillonis dominated down to $10 \mathrm{ft}$. This basin was heavily dredged to make artificial islands and channels and has a high turbidity level, especially during outgoing tide. (This was selected as a "poor" to "difficult" site as opposed to the 36th Street Causeway, which was an optimum but exposed high-energy site.) Considerable tidal currents occur at Margaret Pace Park. Turbidity levels are high, and light penetration to the bottom is low.

Cutler Ridge is an area on the middle western bank of the southern part of North Biscayne Bay which had $348 \mathrm{Mw}$ fossil fuel plants producing electricity and releasing thermal effluents of $\mathrm{a}+7^{\circ} \mathrm{C}$ into the estuary since 1948. It was closed in 1975. During the last years of operation (1968-1969), Smith \& Teas (1977) studied the vegetation and found a large ( $35 \mathrm{ha}$ ) area denuded of Thalassia testudinum, a fringe of Halodule wrightii, and beyond the level of the hottest effluents, a community of Thalassia testudinum. This plant is $16 \mathrm{~km}$ north of the Turkey Point plant on the same coastline and has no other major industrial effluents in the area. Low habitation of the shoreline also occurs here.

\section{TECHNIQUES}

Methods of planting the dominant seagrass, Thalassia testudinum, followed that of Thorhaug (1974). Fruit was collected from nearshore waters, dehisced and held in nursery conditions. Seeds were planted in matrices by hand at intervals of $1 \mathrm{ft}$., beginning from the shoreline and proceeding outward at Margaret Pace Park, and in transects parallel to the shoreline at increasing depths at 36th Street Causeway.

Halodule wrightii was removed in plugs with a post hole digger at 3-ft. intervals from adjacent Halodule wrightii beds on the 36th Street Causeway and Margaret Pace Park sites. A hole was dug at the site by the post hole digger into which the Halodule plug was placed and sand was patted by hand around the plug to stabilize it. This is after the method of Van Breedveld (1976).

Transects of the bottom vegetation at Cutler Ridge were taken in 1977, 1978, and 1979. Investigators gathered the 1977 data by swimming along a series of observational 
grids outward from the mouth of the canal, noting plant communities and any Thalassia seedlings which had been recruited into the area. The 1978 and 1979 studies were done by making formal quantitative counts of the benthic vegetation at $10-\mathrm{m}$ intervals going in fixed directions from the mouth of the effluent.

\section{RESULTS}

The results for the Thalassia seedlings during four measuring periods (November 1978 and February/May/July 1979) from the two sites in North Biscayne Bay are compared with the results taken in 1973-74 from Turkey Point restored Thalassia testudinum seedlings in Table 1. In general, significant growth of blades, roots and rhizomes was seen in the Thalassia seedlings at all three sites. The large growth rates came at the very initiation of the growth period during the early fall, then as the weather warmed in the spring and summer, indicating a temperature-light growth dependency. Rhizomal sprouting and growth came primarily after 6 months and short-shoot growth after 8 months, whereas blade growth occurred vigorously at the very beginning, as did root propagation. The 11-month growth showed continuation of the blade and rhizomelengthening process and the appearance of second and third short-shoot blade growth on a large percentage of the rhizomes. After 8 months, $51 \%$ of those seedlings in North Biscayne Bay had rhizomal or lateral expansion, whereas $89 \%$ of those at Turkey Point did. This indicates greater lateral expansion at Turkey Point than in North Biscayne Bay.

Table 1. Summary of growth rate of restored Thalassia testudinum seedlings in three impacted sites in Biscayne Bay, Miami, Florida (length is given in $\mathrm{cm}$ )

\begin{tabular}{|c|c|c|c|c|c|c|c|}
\hline Stations & $\begin{array}{l}\text { Number } \\
\text { of blades }\end{array}$ & $\begin{array}{c}\text { Longest } \\
\text { blade }\end{array}$ & $\begin{array}{l}\text { Number } \\
\text { of roots }\end{array}$ & $\begin{array}{c}\text { Longest } \\
\text { root }\end{array}$ & $\begin{array}{l}\text { Rhizome } \\
\text { length }\end{array}$ & $\begin{array}{c}\text { Number } \\
\text { with } \\
\text { rhizomes } \\
(\%)\end{array}$ & $\begin{array}{l}\text { Number } \\
\text { with } \\
\text { second } \\
\text { shoot }(\%)\end{array}$ \\
\hline \multicolumn{8}{|l|}{ November (3 mo.) } \\
\hline Turkey Point & 5.0 & 7.6 & n.d. ${ }^{*}$ & 5.9 & 0 & 0 & 0 \\
\hline 36th Street Causeway & 3.7 & 10.8 & 3.3 & 7.8 & 0 & 0 & 0 \\
\hline Margaret Pace Park & 3.6 & 8.0 & 3.6 & 6.9 & 0 & 0 & 0 \\
\hline \multicolumn{8}{|l|}{ February (6 mo.) } \\
\hline Turkey Point & & 15.5 & 8.4 & 6.6 & 5.2 & & \\
\hline 36th Street Causeway & 3.9 & 10.1 & 5.1 & 7.8 & 0.2 & 25 & 0 \\
\hline Margaret Pace Park & 3.7 & 6.7 & 4.2 & 6.8 & 0.2 & 16 & 0 \\
\hline \multicolumn{8}{|l|}{ May (8 mo.) } \\
\hline Turkey Point & 3.7 & 16.5 & 8.6 & 6.8 & 4.7 & 89 & \\
\hline 36th Street Causeway & 4.6 & 11.5 & 6.4 & 7.4 & 1.5 & 53 & 10 \\
\hline Margaret Pace Park & 3.9 & 11.9 & 9.0 & 7.9 & 1.0 & 42 & 0 \\
\hline \multicolumn{8}{|l|}{ July (11 mo.) } \\
\hline Turkey Point & 4.2 & 28.9 & 12.0 & n.d. & 13.5 & 96 & 96 \\
\hline 36th Street Causeway & 4.4 & 27.2 & 7.7 & 7.1 & 6.0 & 85 & 10.2 \\
\hline Margaret Pace Park & 3.8 & 16.7 & 5.3 & 6.7 & 6.6 & 92 & 45.7 \\
\hline
\end{tabular}


Of the two North Biscayne Bay sites, plants from the area with generally clearer water, the 36 th Street Causeway site, had $11 \%$ greater lateral expansion of the rhizomes and $10 \%$ of these had short shoots, whereas none of the Margaret Pace Park plants had short shoots after 8 months. After 11 months, the 36th Street Causeway once more showed a significantly greater proportion of its population having short shoots than that at Margaret Pace Park.

The results at Cutler Ridge showed that in 1977-78 in the area to the mouth of the Cutler Ridge plant there were 17 individual seedlings of Thalassia testudinum found within 10 acres. The bottom was almost entirely barren within $100 \mathrm{~m}$ of the mouth of the effluent. As one progressed toward Chicken Key and toward the spit of land to the south, a zone of patchy Halodule wrightii began appearing and at very infrequent intervals, a patch of Syringodium filiforme. Toward the outer fringes where the Thalassia bed had remained untouched during the effluent, much more dense Halodule wrightii, up to 3000 blades $\mathrm{m}^{-2}$, appeared. In 1979, the survey showed that the density of outer Halodule wrightii had increased up to 4900 blades $\mathrm{m}^{-2}$, and the zone reached into the very mouth of the canal. The middle zone, which had been either barren or extremely patchy, had filled in with light, but homogeneous, quantities of Halodule wrightii. The amount of Thalassia found was one plant in $4500 \mathrm{~m}^{2}$ on one transect; five plants in $8100 \mathrm{~m}^{2}$ on a second transect; and no plants in $4500 \mathrm{~m}^{2}$ on a third transect (one plant per $2850 \mathrm{~m}^{2}$ ).

In 1979, transects showed that Thalassia testudinum could be found as two-year old (3), one-year old (3), and new seedlings in extremely infrequent abundance. The twoyear old plants had progressed to approximately 7 short shoots per seedling; the oneyear old plants had 3 to 4 short shoots per seedling; and the 1979 plant had simply the seed and the blade group. Halodule wrightii had homogeneously covered the area up to the mouth of the canal; although there were now some patches of barrenness, most of the bottom was covered by Halodule wrightii to the edge of the Thalassia testudinum beds at the very outer fringe of the previously denuded area.

\section{DISCUSSION}

The dynamic ecology of the Thalassia ecosystem as outlined from extensive studies adjacent to a power plant in South Biscayne Bay as well as other places in southeast Florida and the Caribbean allowed us to assess the effects of man's impact on the Thalassia community. Restoration efforts after the impact had been removed showed that when the dominant plant species (Thalassia) was replanted, the animal communities returned into the Thalassia matrix within 4 years (McLaughlin et al., in press). It is too early to determine the number of survivors due to the difficulty of observing the longer-bladed Halodule at this time. The survival at the two sites is likely to be different since, due to contractual delays, the Margaret Pace Park was planted 3 days before a heavy storm, while the 36th Street Causeway was planted with 3 weeks of calm weather following.

The criterion used for the comparison of the seagrass recovery at the "optimum" site for North Biscayne Bay (36th Street Causeway) and the "poor" site (Margaret Pace Park) is size versus time. The growth rate of restored seedlings of Thalassia was vigorous in both of these North Biscayne Bay areas and compared favorably with the growth in the singly impacted (thermal impact) area otherwise not degraded in South Biscayne Bay at 
Turkey Point, where water conditions were more favorable. The rhizomal growth is an indication of the rate of lateral expansion of the seedlings; recovery rate of the area is in good part dependent on this. Rhizomal growth after 11 months had occurred to $85 \%$ of the plants at the optimum North Bay site $(6.0 \mathrm{~cm}$ mean length) and $92 \%$ of the plants at the "average" site ( $6.6 \mathrm{~cm}$ mean length), whereas $96 \%$ of the Turkey Point samples had lateral expansion after 11 months, with a mean length of $13.5 \mathrm{~cm}$. After 11 months, appearances of second and third short shoots on the rhizome occurred in $28 \%$ of the North Biscayne Bay plants, while occurring to $96 \%$ of the plants in South Bay (Turkey Point). Thus, more rapid lateral spread occurred at the less polluted area.

Generalized chemical measurements taken by a parallel program (Dade County Department of Environmental Resource Management/DERM) from the North Biscayne Bay sites show that there are not unusual concentrations of any substance known to be a pollutant accumulated at these sites. The salinities, temperatures, and other water parameters fall within normal values for such an estuarine area. However, the chief remnant from 7 decades of man's impact is turbidity due to the large amounts of uncompacted sediment disarranged by various dredging procedures. Turbidity does persist at both of the North Bay sites and is particularly evident during periods of winter cold fronts accompanied by high winds. However, at the Margaret Pace Park during outgoing tides, an increase in turbidity level is definitely noticeable. In addition, a storm sewer runoff occurs here which periodically increases turbidity. One result is that light penetration is less than in South Bay at the same depth. The relationship between light, turbidity, restored seedling growth and rate of restoration of the community in impacted estuaries is thus of prime importance for future investigation.

The rate of recuperation from man's impact in South Biscayne Bay can best be seen at the Cutler Ridge power plant, where no intervention by restoring seagrasses has occurred since the cessation of thermal discharge 3.5 years ago. The successional stage seagrass Halodule wrightii has returned within 3.5 years to cover most of the area with a relatively homogeneous, but in some areas sparse, cover. Extremely infrequent seedlings of Thalassia testudinum occur. From the rate of seed recruitment (one plant per $2850 \mathrm{~m}^{2}$ after 3.5 years) as well as from the rate of lateral growth of the rhizomes, one might extrapolate that 15 to 20 years would be necessary for moderate densities (1500 to 2000 blades $\mathrm{m}^{-2}$ ) of Thalassia to return into this area by natural means. In comparison, the restored area at Turkey Point, $16 \mathrm{~km}$ up the shoreline, had 2030 blades $\mathrm{m}^{-2}$ after 4 years from the cessation of thermal effluent. The area in North Biscayne Bay around the 36th Street Causeway had contained Thalassia (McNulty, 1970). Twenty years after impact, no natural recovery had occurred. The Margaret Pace Park was filled after 1960. Sparse Halodule cover with medium Halophila in deeper waters was the vegetation, so that Thalassia definitely did not naturally recover in this area either.

The effort described yields data beyond that for management tools. The data base for the physiological ecology of Thalassia is enhanced in terms of seedling growth rate, rhizomal lateral expansion rate and successional interaction between the several seagrasses, rate of seedling maturation, age of fruiting of the plant and information about physiological races.

Acknowledgements. The author gratefully acknowledges the support of the U.S. Department of Energy grant FY 76 S-05-4493 and the Florida Power and Light Company for support of the 
restoration at Turkey Point and the support of the Port of Miami and the Miami-Dade Water \& Sewer Authority for the 36th Street Causeway and Margaret Pace Park restoration. The University of Miami Sea Grant program supported the symposia for Biscayne Bay and restoration of North Biscayne Bay. Florida State Senator R. McKnight, with other legislators, has been most effective in obtaining state funds. Dade County Commissioners J. Redford and H. Ruvin have been supportive of the restoration concept. Dade County Environmental Resource Management director C. Morrissey and staff, and Dade County Environmental Planning director R. Walters and staff have been concerned and enthusiastic about implementation of biological rehabilitation of North Biscayne Bay, especially Dr. J. Evoy. Thanks to the many people who participated in various field phases of this, particularly J. Attias, Esq. Dr. E. Man, director of Sea Grant and Dean of Research \& Sponsored Programs at the University of Miami, was implemental to all the initial phases of this project.

\section{LITERATURE CITED}

Bader, R. G. \& Roessler, M. A., 1971. An ecological study of South Biscayne Bay and Card Sound, Florida. - Prog. Rep. to U.S. Atomic Energy Commn, Miami. AT 40-1-3801-3.

Bader, R. G. \& Roessler, M. A., 1972. An ecological study of South Biscayne Bay and Card Sound, Florida. - Prog. Rep. to U.S. Atomic Energy Commn, Miami. AT 40-1-3801-4.

Bader, R. G., Roessler, M. A. \& Thorhaug, A., 1973. The environmental impact of a power plant on a subtropical bay. - Trans. Am. nucl. Soc. 16 (S-1), 15.

Breedveld, J. van., 1976. Transplanting of seagrasses with emphasis on the importance of substrate. - Fla mar. Res. Publs 126, 1-26.

McLaughlin, P. A. \& Thorhaug, A., 1978. Preliminary report on recolonization of invertebrates into a Thalassia testudinum restoration site. - Fla Scient. 41 (S), 19. (Abstract.)

McLaughlin, P. A. \& Thorhaug, A., 1979. Restoration of Thalassia testudinum: animal community in a maturing four-year-old site - preliminary results. In: Proceedings of the 5 th annual conference on restoration of coastal vegetation in Florida. Ed. by D. P. Cole. Hillsborough Community College Press, Tampa, Fl, 149-161.

McLaughlin, P. A., Thorhaug, A., Treat, S. \& Lemaitre, R. The animal community in a restored seagrass (Thalassia testudinum) bed. - Aquat. Bot. (In press.)

McNulty, J. K., 1970. Effects of abatement of domestic sewage pollution on the benthos: Volumes of zooplankton and the fouling organisms of Biscayne Bay, Florida. University of Miami Press, Coral Gables, Florida, 1-107.

Roessler, M. A., Tabb, D. C., Rehrer, R. \& Garcia, J., 1974. Studies of effects of thermal pollution in Biscayne Bay, Florida. - EPA ecol. Res. Ser. EPA 660/3-74-014, 1-145.

Smith, R. C. \& Teas, H. J., 1977. Biological effects of thermal effluent from the Cutler Ridge power plant in Biscayne Bay, Florida. In: Proceedings of the conference on waste heat management and utilization. Ed. by S. S. Lee \& S. Sengupta. University of Miami, Coral Gables, Fl, IIB91IIB106.

Thorhaug, A., 1974. Transplantation of the seagrass Thalassia testudinum König.-Aquaculture 4, 177-183.

Thorhaug, A. (Ed.), 1976. Biscayne Bay: Past, present, future. - Sea Grant spec. Rep. University of Miami, Coral Gables, Fl, 5, 1-165.

Thorhaug, A., 1979. The flowering and fruiting of restored Thalassia beds: a preliminary note. Aquat. Bot. 6, 189-192.

Thorhaug, A. Recovery patterns of restored major plant communities in the U.S.: high to low altitude, desert to marine. In: Proceedings of the symposium on recovery patterns in damaged ecosystems. Ed. by University of Georgia, Athens, Ga. (In press.)

Thorhaug, A. \& Austin, C. B., 1976. Restoration of seagrasses with economic analysis. - Environ. Conserv, 3 (4), 259-268.

Thorhaug, A. \& Hixon, R., 1975. Revegation of Thalassia testudinum in a multiple-stressed estuary, North Biscayne Bay, Florida. In: Proceedings of the 2nd annual conference on restoration of coastal vegetation in Florida. Ed. by R. Lewis. Hillsborough Community College Press, Tampa, Fl, 12-27. 
Thorhaug, A. \& Roessler, M. A., 1977. Seagrass cormmunity dynamics in a substropical estuarine lagoon. - Aquaculture 12, 253-277.

Thorhaug, A., Roessler, M. A., Bach, S., Josselyn, M., Hixon, R. \& Brook, I., 1979. Thermal effluent discharges from a power plant into Card Sound, Florida: Observations before, during and after, Environ. Conserv. 6 (2), 172-173.

Thorhaug, A., Segar, D. \& Roessler, M. A., 1973. Impact of a power plant on a subtropical estuarine environment. - Mar. Pollut. Bull. 4, 166-169.

Tomlinson, P. B., 1974. Vegetative morphology and meristem dependence - the foundation of productivity in seagrasses. - Aquaculture 4, 107-130. 